\title{
IMPACT OF THE MOSQUITO BUG (HELOPELTIS THEIVORA) INFESTATION ON THE QUALITY OF TEA (CAMELLIA SINENSIS)
}

\author{
Razia Sultana Chowdhury, Irin Siddiqua Moly, Mainuddin Ahmed ${ }^{1}$, Mohammad \\ Shameem Al Mamun², Md. Mozammel Hoque and Md. Faruque Miah* \\ Department of Food Engineering and Tea Technology, Shahjalal University of \\ Science and Technology, Sylhet, Bangladesh
}

\begin{abstract}
The influence of tea mosquito bug (Helopeltis theivora) infestation on the physiological and biochemical changes in tea leaves as well as quality parameters of the made tea was investigated. Results revealed that physiological parameters such as polyphenol, chlorophyll a and b, carotenoids, catechins, reducing sugar and antioxidant activity reduced when the shoots are infested by tea mosquito bug. Black tea prepared from Helopeltis infested shoots contained significantly lower amount of theaflavin and thearubigin ratio, highly polymerized substances, total liquor colour, colour index, caffeine and lipid than that of uninfested fresh tea leaves. The infestation of tea mosquito bug significantly reduced the physiological parameters of tea leaves and quality parameters of made tea that hamper the quality of drinking tea.
\end{abstract}

Key words: Tea leaves, mosquito bug, infestation, quality

\section{INTRODUCTION}

Tea is the most popular non-alcoholic stimulating beverage in the world as well as one of the healthiest drinks made from the tender shoots of tea plant, Camellia sinensis (Kuntze) of Theaceae. Tea leaves contain several chemical compounds having medicinal properties such as caffeine, polyphenol and alkaloids. Tea production is greatly hindered by many factors. In world tea, 1034 species of arthropods and 82 species of nematodes are associated with tea plants (Chen and Chen 1989). In Bangladesh tea, so far 25 insects, 4 mites and 10 species of nematodes have been recorded (Ahmed 2005). Different pests (insects, mites and nematodes) alone can extensively damage the crop to the tune of $10-15 \%$ per annum (Sana 1989, Ahmed 2005) and in severe cases; it would be 100\% (Mamun and Ahmed 2011).

Tea mosquito bug (Helopeltis theivora, Waterhouse) is the most notorious pest of tea in almost all tea producing countries including Bangladesh. The pest causes serious damage to tea leaves which is found in greater Sylhet region of

*Author for correspondence: faruque-btc@sust.edu ${ }^{1}$ Biochemistry Division, Bangladesh Tea Research Institute, Srimangal, Moulvibazar, Bangladesh. ${ }^{2}$ Entomology Division, Bangladesh Tea Research Institute, Srimangal, Moulvibazar, Bangladesh. ${ }^{3}$ Department of Genetic Engineering and Biotechnology, Shahjalal University of Science and Technology, Sylhet-3114, Bangladesh.

(C) 2016 Zoological Society of Bangladesh DOI: 10.3329/bjz.v44i2.32759 
Bangladesh. Records show the serious notice of the pest since 1957 (Sana 1989). Helopeltis infestation occurred in the recently opened tea area in Panchagarh (extreme north-west of Bangladesh). Both nymphs and adult cause damage by sucking the sap from succulent stems, buds and young leaves by inserting the proboscis. From the economic point of view, the pest is considered to be the major one causing damage to tea both in respect of quantity and quality.

Pest infestation deteriorates the quality of food, fruits and beverages including tea. Despite crop loss, pest infestation also adversely affects the quality of processed tea. The severe infestation by flush worm, mites, thrips and tea mosquito bug adversely affected flavor and decreased the polyphenolic content (Murthy and Chandrasekaran 1979). The quantity of crop loss in respect of yield due to the infestation of Helopeltis was assessed in different regions of the world (Rao and Murthy 1976, Muraleedharan 1991, Barbora et al. 2000, Ahmed 1996), but there is very little information on the physiological and biochemical as well as quality deterioration of made tea caused by the infestation of Helopeltis. Therefore, present study was designed to determine the effect of tea mosquito bug infestation on the physiological and biochemical changes in green leaves as well as quality of drinking tea.

\section{MATERIAL AND METHODS}

Pluckable shoots comprising "two leaves and a bud" were collected from the experimental plots of BTRI main farm where the plots were divided into two categories such as (1) fresh leaves plot and (2) Helopeltis infested plot. These leaves were collected for the analysis both green leaf and made tea. This experiment was conducted at the laboratory of Department of Food Engineering and Tea Technology, Shahjalal University of Science and Technology (SUST), Sylhet and Bangladesh Tea Research Institute (BTRI), Moulvibazar, Bangladesh.

Estimation of chlorophyll and carotenoids contents: Chlorophyll content of tea shoots was measured following Wellburn (1994) by using UV-visible spectrophotometer. Pigments, chlorophyll a, b and carotenoids were calculated using the formulae like chlorophyll $\mathrm{a}=(15.65$ A666 - 7.34 A653), chlorophyll b $=(27.05$ A653 -11.21 A666 $)$ and carotenoids $=(1000$ A470 -2.86 chlorophyll a - 129.2 chlorophyll b)/221, while the chlorophyll and carotenoids values were expressed as milligram per gram (mg/g) fresh weight basis.

Estimation of polyphenols, catechins and reducing sugars: The alcoholic extract of tea samples was used for estimation of polyphenols, catechins and reducing sugars. Absorbance of the alcoholic extract was read at $700 \mathrm{~nm}$ against the reagent blank considering the development of blue color using UV-visible 
spectrophotometer. Quantum of polyphenols present in tea leaves was computed using the standard calibration curve derived from known concentrations (10 to $50 \mathrm{ppm}$ ) of gallic acid and the results were expressed as per cent gallic acid equivalents (Choudhury and Gowsami 1983). In the case of catechins determination of experimental samples, absorbance was read at $510 \mathrm{~nm}$ against the reagent blank in UV-visible spectrophotometer and amount of catechins present in tea leaves was calculated using the standard calibration curve computed with the values obtained against known concentrations (10 to $50 \mathrm{ppm}$ ) of $(+)$ catechin and the results were expressed as per cent catechin equivalents (Swain and Hillis 1959). Furthermore, reducing sugar was estimated whereas absorbance of the green color developed was read at $630 \mathrm{~nm}$ against the reagent blank in a UV-visible spectrophotometer and per cent reducing sugars (dextrose equivalents) present in tea samples was computed using the standard calibration curve where known concentrations of $(+)$ dextrose were used to derive calibration curve (Hedge and Hofreiter 1962).

Determination of total antioxidant: The scavenging effects of samples for 1,1diphenyl-2-picrylhydrazyl (DPPH) radical were monitored following Yen and Chen (1995) where the absorbance was read at $517 \mathrm{~nm}$ in UV-visible spectrophotometer. The ability to scavenge the DPPH radical was calculated as scavenging effect $(\%)=[1$ - (A sample - A sample blank $) /$ A control $] \times 100$, where, a control is the absorbance of the control (DPPH solution without sample), A sample is the absorbance of the test sample (DPPH solution plus test sample) and A sample blank is the absorbance of the sample only (sample without DPPH solution). Synthetic antioxidants: Butylated hydroxytoluene (BHT), gallic acid and ascorbic acid were used as positive controls.

Determination of total tannin content: The tannins were determined using the Folin-ciocalteu phenol reagent as reported by Amorim et al. (2008). A set of standard solutions of tannic acid was read against a blank using UV-visible spectrophotometer. The results of tannins were expressed in terms of tannic acid in $\mathrm{mg} / \mathrm{g}$ of dry extract. Total tannin content was determined as $\mathrm{mg}$ of tannic acid equivalent per gram using the equation obtained from a standard tannic acid calibration curve $\mathrm{y}=0.008 \mathrm{x}+0.005, \mathrm{R} 2=0.997$.

Observation of quality of made tea: Black tea was manufactured by using miniature of CTC (crush, tear and curl) unit (Thanaraj and Seshardi 1990). Crushed sample was kept in a cabinet fermenter at $25^{\circ} \mathrm{C}$ and $95 \%$ relative humidity. Optimum fermentation time was assessed adopting the method as reported by Ullah (1977). Fermented dhool was dried in a drier at $120^{\circ} \mathrm{C}$ for 2 hours which reduced the moisture content to around 3\%. Tea samples thus manufacture and were stored for analysis (Kumar 2004). Contents of theaflavin 
(TF), thearubigin (TR), highly polymerized substances (HPS) and total lliquor colour (TLC) were estimated from the absorbance values (Fig. 1).

Contents of TF, TR, HPS and TLC were calculated by the following formulae : $\mathrm{TF}(\%)=(4.313 \times \mathrm{C} \times 2 \times 100) /($ Sample weight $\times$ dry matter content $), \mathrm{TR}(\%)=$ $(13.643 \times(B+D-C) \times 2 \times 100) /($ Sample weight $\times$ dry matter content $)$, HPS $(\%)=$ $(13.643 \times \mathrm{E} \times 2 \times 100) /($ Sample weight $\times$ dry matter content) and TLC $(\%)=(10$ $\times \mathrm{A} \times 2 \times 100) /($ Sample weight $\times$ dry matter content).

Multiplication factors of $\mathrm{TF}$ and $\mathrm{TR}$ were derived from molar extinction coefficients of pure compounds and dilution factor (Roberts and Smith 1963). In the case of TLC, value 10 is the dilution factor (Thanaraj and Seshadri 1990). Colour index was derived using the formula as $\mathrm{CI}=(\mathrm{TF} * 100) /(\mathrm{TR}+\mathrm{HPS})$ as reported by Ramaswamy (1986).

Quantification of lipids: Quantification of lipid present in the leaf material was calculated gravimetrically and expressed as per cent according to Ravichandran and Parthiban (2000) where the formula was considered as lipid $(\%)=$ weight of dried dish - weight of empty dish $\times 100$.

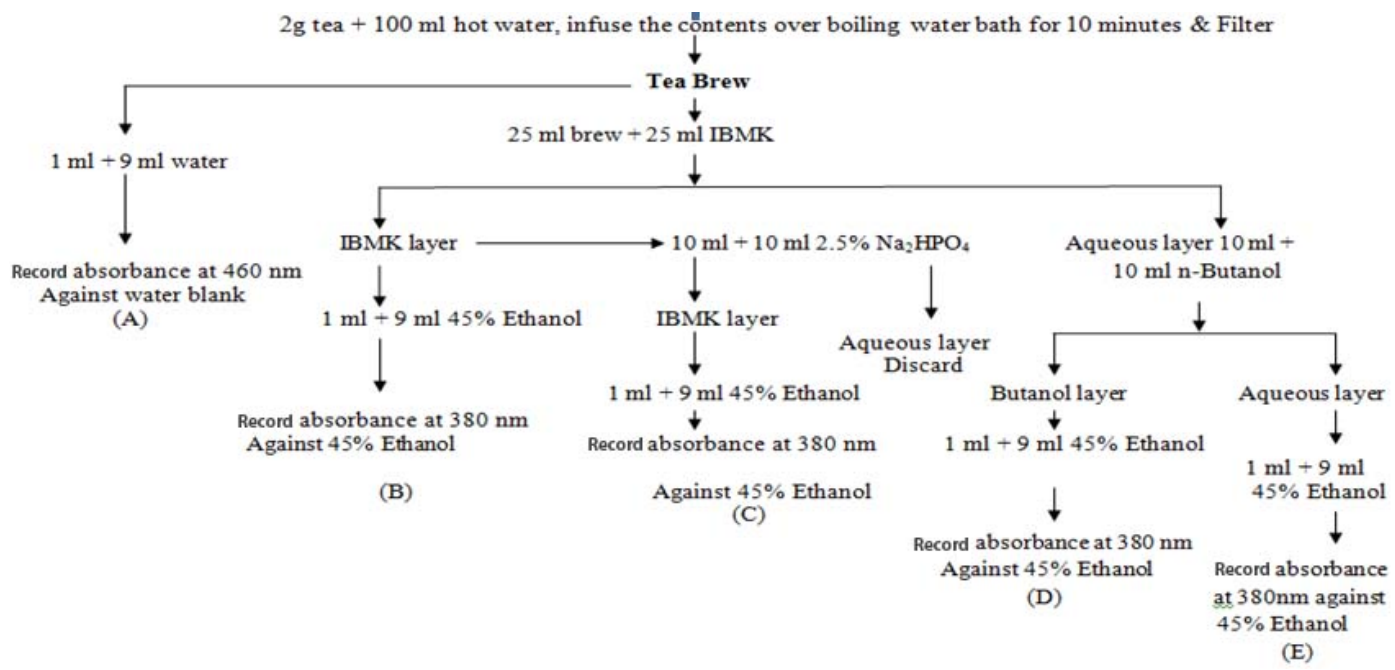

Fig. 1. Estimation of TF, TR, HPS and TLC in black tea by spectrophotometer.

Estimation of caffeine: The presence of caffeine in the tea samples was measured through UV-visible spectrophotometer and absorbance was compared in $260 \mathrm{~nm}$. Quantum of caffeine present in tea leaves was computed using the standard calibration curve derived from known concentrations ( 0 to $20 \mathrm{ppm}$ ) of caffeine and the results were expressed as per cent caffeine equivalents (Maidon et al. 2012). 
Determination of total ash: Total ash was estimated by directly incineration of sample taken in a crucible according to AACC (2000) method 08-01, by using the calculated of ash $(\%)=($ Wt. of ash $) /$ Wt. of sample $) \times 100$. Acid insoluble ash was measured as, acid insoluble ash $(\%)=($ Wt. of ash $\times 100 \times 100) /(\mathrm{Wt}$. of sample $\times(100$-moisture) and water soluble ash were measured using the formula such as water soluble ash $(\%)=\{($ Total ash - water insoluble ash $) \times$ 10,000)/(Total ash $\times(100$-moisture $)$.

Dry matter and moisture content: The moisture content was measured according to the official method 44-01 of AACC (2000). The moisture content of the sample was calculated using the following formulae: Dry matter content $(\mathrm{DMC})(\%)=(\mathrm{Wt} \text {. of dried sample }(\mathrm{g}))^{*} 100 / \mathrm{Wt}$. of fresh sample $(\mathrm{g})$ and moisture $(\%)=100-$ dry matter.

Water extract: The water extract of tea samples was measured by using a formula and the formula was, water extract $(\%=$ (weight of extract $\times 100 \times 100 \times$ 5) / (sample weight $\times$ (100-moisture).

Statistical analysis: All measurements and analyses were expressed as means \pm standard deviation of measurements. The results were analyzed statistically using the MS Excel program to determine the average value and standard error of the mean (SEM).

\section{RESULTS AND DISCUSSION}

Chlorophyll and carotenoids contents: Chlorophyll a, b and carotenoids of tea mosquito bug (TMB) infested and fresh tea leaves were observed (Fig. 2). Result revealed that fresh tea leaves contain $2.73 \mathrm{mg} / \mathrm{g}$ chlorophyll a, $1.23 \mathrm{mg} / \mathrm{g}$ chlorophyll $\mathrm{b}$ and $1.11 \mathrm{mg} / \mathrm{g}$ carotenoids, respectively. Infested tea leaves contain $2.24 \mathrm{mg} / \mathrm{g}$ chlorophyll a, $1.03 \mathrm{mg} / \mathrm{g}$ chlorophyll b and $0.51 \mathrm{mg} / \mathrm{g}$ carotenoids, respectively. In this case it was found that chlorophyll $a, b$ and carotenoids were high in fresh leaves and low in the infested leaves.

Total polyphenols, catechins, tannins and reducing sugars: Total polyphenols, catechins, tannins and reducing sugars contents in fresh and infested leaves of tea mosquito bug were observed (Table 1). Result revealed that polyphenol content was found higher in fresh tea leaves $(56.65 \mathrm{ppm})$ than the Helopeltis infested leaves (45.24 ppm). The catechin content in fresh leaves was also found higher $(25.24 \mathrm{ppm})$ than the infested leaves (18.69 ppm). The lower amount of tannin content $(18.69 \mathrm{mg} / \mathrm{g})$ was found in fresh leaves whereas the higher amount of tannin $(21.30 \mathrm{mg} / \mathrm{g})$ was found in the infested leaves. The reducing sugar level in fresh leaves was found higher (46.90 ppm) than the infested leaves (34.73 ppm) as well. 


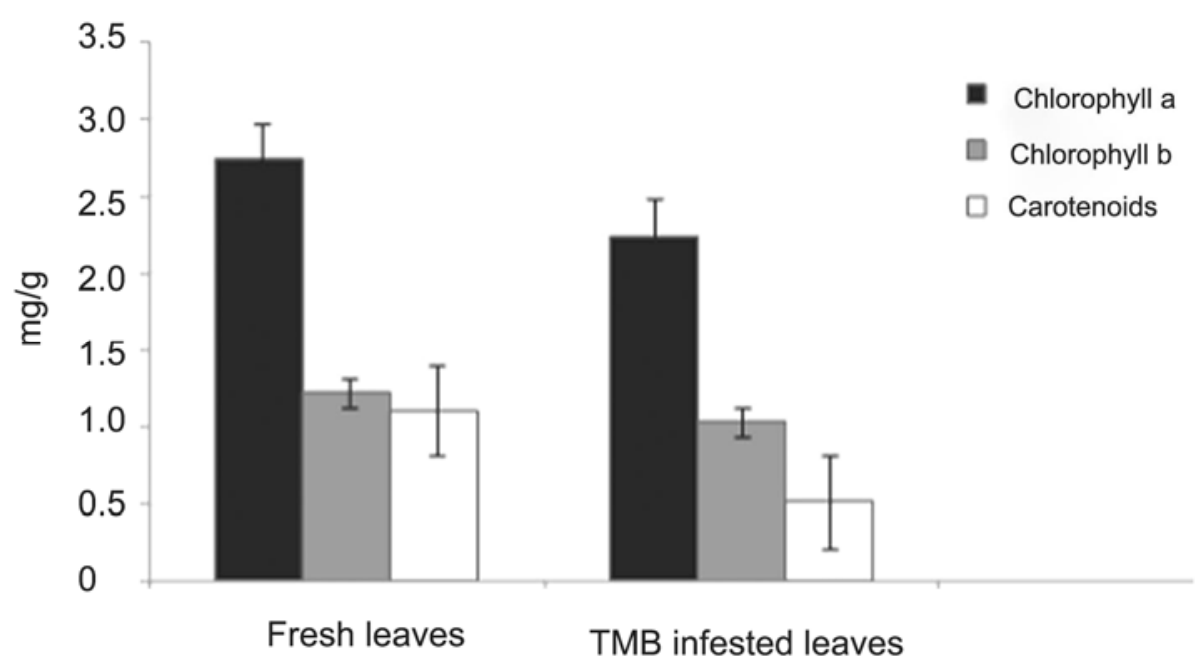

Fig. 2. Chlorophylls and carotenoids of fresh and TMB infested leaves.

Table 1. Polyphenols, catechins and reducing sugars in Helopeltis infested leaves

\begin{tabular}{lll}
\hline Biochemical parameters & Fresh leaves & Helopeltis infested leaves \\
\hline Polyphenols (ppm) & $56.65 \pm 0.83$ & $45.24 \pm 0.38$ \\
Catechins (ppm) & $25.24 \pm 0.49$ & $18.69 \pm 0.09$ \\
Tannins (mg/g) & $18.69 \pm 0.09$ & $21.30 \pm 0.14$ \\
Reducing sugars (ppm) & $46.90 \pm 0.36$ & $34.73 \pm 0.29$ \\
\hline
\end{tabular}

Total antioxidant: The antioxidant activity of the methanolic extract of fresh leaves and TMB infested leaves was evaluated by free radical scavenging assay (Table 2). Fresh tea leaves extracts exhibited higher scavenging effect on 2,2diphenylpicrylhydrazyl (DPPH) radicals such as 90.12, 88.13, 87.90, 86.19 and $84.32 \%$ for $50,10,2,0.4$ and $0.08 \mathrm{mg} / \mathrm{ml}$, respectively. But TMB infested leaves exhibited lower scavenging effect on DPPH radicals such as $86.30,84.45,84.10$, 79.91 and $77.07 \%$ for $50,10,2,0.4$ and $0.08 \mathrm{mg} / \mathrm{ml}$, respectively. So, it was found that antioxidant activity was reduced in tea leaves due to attack of tea mosquito bug.

Quality of made tea: Lower amount of TF, TR, TF:TR, HPS, TLC and CI (color index) was found in black tea which was manufactured by tea mosquito bug infested leaves and the higher value of theaflavin (TF), TThearubigin (TR), highly polymerized substances (HPS), total liquor color (TLC) and CI was found in fresh leaves (Table 3), whereas the better quality of tea is considered between the ratio of $\mathrm{TR}$ and $\mathrm{TF}$ must be 10 and in this research the appropriate ratio was also found in fresh leaves but gradually decreased in tea mosquito bug infested leaves. 
Estimation of different physico-chemical parameters: Different physicochemical parameters such as lipid, caffeine, total ash, water soluble ash, acid insoluble ash, alkalinity of water soluble ash, water extract, moisture and dry matter content of fresh and tea mosquito bug infested leaves were estimated (Table 4) and the lipid was found between 3.93 and $4.83 \%$ where the fresh tea leaves sample contain $4.83 \%$ and low infested leaves contain $3.93 \%$. The highest (62.27 ppm) caffeine was observed in fresh tea leaves sample and lowest (54.96 $\mathrm{ppm})$ was found in infested leaves. The total ash in the fresh tea leaves was found lower $(5.54 \%)$ than the infested leaves (6.07\%). Furthermore, the water

Table 2. Antioxidant activity of fresh and TMB infested tea leaves at different concentrations

\begin{tabular}{llllll}
\hline Samples & \multicolumn{5}{c}{ Scavenging effect $(\%)$} \\
\cline { 2 - 6 } & $50(\mathrm{mg} / \mathrm{ml})$ & $10(\mathrm{mg} / \mathrm{ml})$ & $2(\mathrm{mg} / \mathrm{ml})$ & $0.4(\mathrm{mg} / \mathrm{ml})$ & $0.08(\mathrm{mg} / \mathrm{ml})$ \\
\hline Gallic acid & $97.88 \pm 0.68$ & $94.05 \pm 0.46$ & $93.44 \pm 0.99$ & $90.99 \pm 0.71$ & $87.56 \pm 0.58$ \\
Ascorbic acid & $96.99 \pm 0.83$ & $93.63 \pm 1.14$ & $92.73 \pm 1.42$ & $92.15 \pm 0.90$ & $91.39 \pm 1.33$ \\
Fresh leaves & $90.12 \pm 0.15$ & $88.13 \pm 1.14$ & $87.90 \pm 0.09$ & $86.19 \pm 0.08$ & $84.32 \pm 0.15$ \\
TMB infested leaves & $86.30 \pm 0.68$ & $84.45 \pm 0.64$ & $84.10 \pm 0.15$ & $79.91 \pm 0.30$ & $77.07 \pm 0.08$ \\
\hline
\end{tabular}

Table 3. TR, TF, TF:TR, HPS, TLC and CI content in fresh and TMB infested leaves

\begin{tabular}{lll}
\hline Quality parameters & Fresh leaves & TMB infested leaves \\
\hline TF $(\%)$ & $0.67 \pm 0.03$ & $0.62 \pm 0.02$ \\
TR (\%) & $6.76 \pm 0.09$ & $6.19 \pm 0.08$ \\
TF: TR & $10.09 \pm 0.10$ & $9.84 \pm 0.10$ \\
HPS (\%) & $6.20 \pm 0.09$ & $5.98 \pm 0.08$ \\
TLC (\%) & $2.54 \pm 0.08$ & $2.36 \pm 0.42$ \\
Colour index (CI) & $5.16 \pm 0.07$ & $5.16 \pm 0.06$ \\
\hline
\end{tabular}

soluble ash in the tea was found 44.55 and $40.25 \%$ in terms of total ash for fresh leaves and infested leaves, respectively. Acid insoluble ash of different grades of tea leaves was $1 \%$ whereas in this experiment fresh tea leaves sample contain $1.04 \%$ and infested leaves contain $1.09 \%$. Alkalinity of water soluble ash in the tea samples were found 3.06 and $3.65 \%$ in terms of total ash for fresh and infested leaves, respectively. The percentage of ash was gradually increasing in the fresh leaves against the infested leaves and highest in infested leaves.

Water extract of Helopeltis infested and uninfected tea leaves was observed where the water extract content was highest $33.65 \%$ in fresh leaves and lower $26.42 \%$ in the highly infested leaves. The amount of moisture of fresh tea leaves sample contains $3.15 \%$ and infested leaves contain $2.69 \%$. Dry matter content measured in different sample was observed and found $96.85 \%$ in fresh tea leaves and $97.08 \%$ in infested leaves. 
Feeding punctures made by TMB appeared as reddish brown spots. Severely infested leaves turned black in colour and curled downwards resulting active photosynthetic area is also reduced. Increased polyphenol oxidase activity was attributed to the conversion of polyphenols to quinines as reported earlier in eriophyid mite infested citrus leaves. Quinones in plant tissue react with proteins to form melanin and other tannins. Discoloration of damaged leaves was attributed to the accumulation of tannins as reported in citrus (Ishaaya and Sternlicht 1971).

Table 4. Compositions of different physico-chemical parameters in fresh and TMB infested leaves

\begin{tabular}{lll}
\hline Quality parameters & Fresh leaves & TMB infested leaves \\
\hline Lipid (\%) & $4.83 \pm 0.06$ & $3.93 \pm 0.05$ \\
Caffeine (ppm) & $62.27 \pm 0.84$ & $54.96 \pm 0.63$ \\
Total ash content (\%) & $5.54 \pm 0.06$ & $6.07 \pm 0.11$ \\
Water soluble ash (\%) & $44.55 \pm 0.68$ & $40.25 \pm 0.66$ \\
Acid insoluble ash (\%) & $1.04 \pm 0.01$ & $1.09 \pm 0.01$ \\
Alkalinity of water soluble ash (\%) & $3.06 \pm 0.04$ & $3.65 \pm 0.03$ \\
Water extract (\%) & $33.65 \pm 0.30$ & $26.42 \pm 0.28$ \\
Moisture content (\%) & $3.15 \pm 0.02$ & $2.69 \pm 0.04$ \\
Dry matter content (\%) & $96.85 \pm 0.21$ & $97.08 \pm 0.28$ \\
\hline
\end{tabular}

Despite the increase in dry matter content, both biochemical constituents and physiological parameters decreased with the increasing level of TMB infestation. Similar results have been reported in cashew nut and Pongameag labra infested by Helopeltis antonii and eriphyid mites, respectively (Nagaraja et al.1994, Manjunath et al. 1989). The tea leaves were severely infested by flushworm, mites, thrips and tea mosquito bug adversely affected flavor and decreased the polyphenolic content (Murthy and Chandrasekaran 1979, Sudhakaran et al. 2000). Tea made from flushworm infested shoots had low levels of extractable solids and high crude fiber content (Murthy and Chandrasekaran 1979). Mamun et al. (2016) also found the similar trend of result in case of red spider mite infesting tea. They found that the physiological and biochemical contents were significantly $(p>0.05)$ reduced with the increase of infestation (from low to high) of red spider mites. Photosynthetic pigments such as chlorophyll a $(2.0 \mathrm{mg} / \mathrm{g})$ and $\mathrm{b}(1.05 \mathrm{mg} / \mathrm{g})$, carotenoids $(0.55 \mathrm{mg} / \mathrm{g})$ and biochemical components such as polyphenols (45.56 ppm), catechins (10.40 $\mathrm{ppm})$ and reducing sugar (34.57 ppm) in severely infested green leaves were found lower than the fresh leaves. Black tea manufactured from severely infested leaves had the lower amount of theaflavin $(0.43 \%)$, high polymerized 
substances $(6.16 \%)$, total liquor colour $(2.20 \%)$, colour index (3.27), lipid $(3.77 \%)$, caffeine $(54.68 \mathrm{ppm})$, moisture content $(0.63 \%)$ and water extract $(22.66 \%)$ but it was reverse in case of Thearubigin $(7.00 \%)$, total ash $(5.70 \%)$ and dry matter (99.37\%). Made tea manufactured from mite infested shoots was valued inferior (31.65 - 32.90) when subjected to organoleptic evaluation. Similar observation towards changes of physio-biochemical parameters in tea leaves and made tea due to Helopeltis infestation was also reported by Sudhakaran et al. (2000). They studied on the influence of tea mosquito bug, Helopeltis theivora infestation the photosynthetic rate $(\mathrm{Pn})$, biochemical constituents of green leaf and quality parameters of black tea. Biochemical constituents such as chlorophyll, carotenoids, polyphenols, catechins, amino acids and total sugars were very much reduced when the shoots were severely infested.

It is concluded that, the present study provides good information about the severity of tea mosquito bug infestation and its adverse effects on the quality of made tea. Most of the physio-biochemical parameters such as chlorophyll, polyphenols, reducing sugar, total antioxidant, tannins, caffeine, ash, color index, etc. were found much lower in the infested leaves compared to that of fresh leaves. By the attack of tea mosquito bug, the production of tea leaves is also reduced and consequently, it will negatively affect the national economy of Bangladesh, where tea is one of the major sources of earning foreign currency. So, further research is needed to control the gradual tea mosquito bug invasion in our tea gardens to safeguard the quality and sustainable production of tea.

\section{LITERATURE CITED}

AACC. 2000. Approved methods of the American Association of Cereal Chemists. 10th ed. The Association, St. Paul, MN, US. pp. 1200.

AHMED, M. 2005. Tea Pest Management, Evergreen Printing and Packing, Dhaka. p. 118.

AHMED, M. 1996. Relationship between infestation intensity and crop loss by Helopeltis in tea. Tea J. Bangladesh 32 (1\&2): 20-30.

AMORIM, E.L.C., NASCIMENTO, J.E., MONTEIRO, J.M., PEIXOTO SOBRINO, T.J.S., ARAUJO, T.A.S. and ALBUQUER, U.P. 2008. A simple and accurate procedure for the determination of tannin and flavanoid levels and some applications in ethnobotany. Fun. Eco. Comm. 2(1):88-94.

BARBORA, L., BAIRD, C. and GRAHAME, W.G. 2000. Microbiological Safety and Quality of Food. pp. 960-964.

CHEN, Z.M. and CHEN, X.F. 1989. An analysis of world tea pest fauna. J. Tea Sci. 9: 13-22.

CHOUDHURY, N.D. and GOWSAMI, M.R. 1983. A rapid method for determination of total phenolic matter in tea (Camellia sinensis L.). Two and a Bud. 30: 59-61.

HEDGE, J.E. and HOFREITER, B.T. 1962. In: Carbohyd. Chem. 17 (Eds.) Whistler, R. L. and Bemiller, J.N., Academic Press, New York. p. 420. 
ISHAAYA, I. and STERNLICHT, M. 1971. Oxidative enzymes, ribonuclease and amylase inlemon buds infested with Aceria sheldoni (Ewing) (Acarina: Eriophyidae). J. Expl. Bot. 22: 146-152.

KUMAR, R.S.S. 2004. Studies on improving quality of south Indian black teas. Final technical report submitted to Tea Board, Kolkata, India. p. 71.

MAIDON, A.B.M.A., MANSOER, A.O. and SULISTYARTI, H. 2012. Study of various solvents for caffeine determination using UV spectrophotometer. J. Appl. Sci. Res. 8(5): 2439-2442.

MAMUN, M.S.A. and AHMED, M. 2011. Prospect of indigenous plant extracts in tea pest management. Int. J. Agril. Res. Innov. \& Tech. 1 (1-2): 16-23.

MAMUN, M.S.A., HOQUE, M.M., AHMED, M. and YASIN, M. 2016. Physiological and biochemical changes in tea leaves and made tea due to red spider mite infestation. Asian J. Plant Sci. 15: 16-25.

MANJUNATH, M., BHAT, N.S. and PUTTAWAMY, N. 1989. Morphology, histopathology, histochemistry and biochemical constituents of mite (Aceria pongamiae) induced leaf galls and healthy leaves of Pongamia glabra. In: Progress in Acarology, (Eds. Chnna Basavanna, G.P. and Virakatamath, C.A.) Oxford IBH, New Delhi. pp. 141-146.

MURALEEDHARAN, N. 1991. Pest Management in Tea, The United Planters' Association of South India (UPASI) Tea Research Institute, Valparai, Tamil Nadu, India. pp. 1-19.

MURTHY, R.L.N. and CHANDRASEKARAN, R. 1979. Effect of pest damage on the quality of made tea. pp. 375-283. In: Plant protection (entomology, microbiology, nematology, plant pathology and rodentology). Proceedings of Plantation Crops Symposium II. Eds. C.S. Venkataram, Indian Society for plantation crops, Kasaragod, Kerala, India.

NAGARAJA, K.V., BHAVANISHANKARA G.P.S., VENUGOPALAKRISHNA K. V. and JOY N. 1994. Biochemical changes in cashew in relation to infestation by tea mosquito bug. Plant Physio. Biochem. 21: 91-97.

RAMASWAMY, S. 1986. Improving tea quality in south India. UPASI Tea Scientific Department Bulletin 42: 12-24.

RAO, G.N. and MURTHY, R.L.N. 1976. Economics of tea pest control. UPASI Tea Scientific Department Bulletin 33: 88-100.

RAVICHANDRAN, R. and PARTHIBAN, R. 2000. Lipid occurrence, distribution and degradation to flavor volatiles during tea processing. Food Chem. 68: 7-13.

ROBERTS, E.A. and SMITH, R.F. 1963. The phenolic substance of manufactured tea IX. The spectrophotometric evaluation of tea liquors. J. Sci. Food Agri. 14: 689- 700.

SANA, D.L. 1989. Tea Science. Ashrafia Boi Ghar, Dhaka, 272.

SUDHAKARAN, R., SELVASUNDARAM, R. and MURALEEDHARAN, N. 2000. Physiological and biochemical changes in tea leaves due to tea mosquito bug infestation. In: Recent advances in plant crops research, Allied publisher Ltd., Chennai, India. pp. 289-292.

SWAIN, T. and HILLIS, W.E. 1959. The phenolic constitutes of Prunus domesticates I. The quantitative analysis of phenolic constituents. J. Sci. Food Agri. 10: 6368.

THANARAJ, S.N.S. and SESHARDI, R. 1990. Influence of polyphenol oxidase activity and polyphenol content in tea shoot on quality of black Tea. J. Sci. Food Agri. 51: 57-69.

ULLAH, M.R. 1977. Alternative test for assessment of fermentation. In: Proceeding of the 29th Tocklai conference, (TC"77), Assam, India. pp. 75-77. 
WELLBURN, A.R. 1994. The spectral determination of chlorophylls a and b as well as total carotenoids, using various solvent with spectrophotometers of different resolution. J. Plant Physiol. 144: 307-313.

YEN, G.C. and CHEN, H.Y. 1995. Antioxidant activity of various tea extracts in relation to their antimutagenicity. J. Agril. Food Chem. 43(1): 27-32.

(Manuscript received on 25 July, 2016; revised on 6 November, 2016) 